\title{
Unorden
}

\section{Kvalitet og relevans i uddannelser og forskning}

Samarbejdsprogram for Nordisk Ministerråd for Uddannelse og Forskning (MR-U) gældende fra 2015

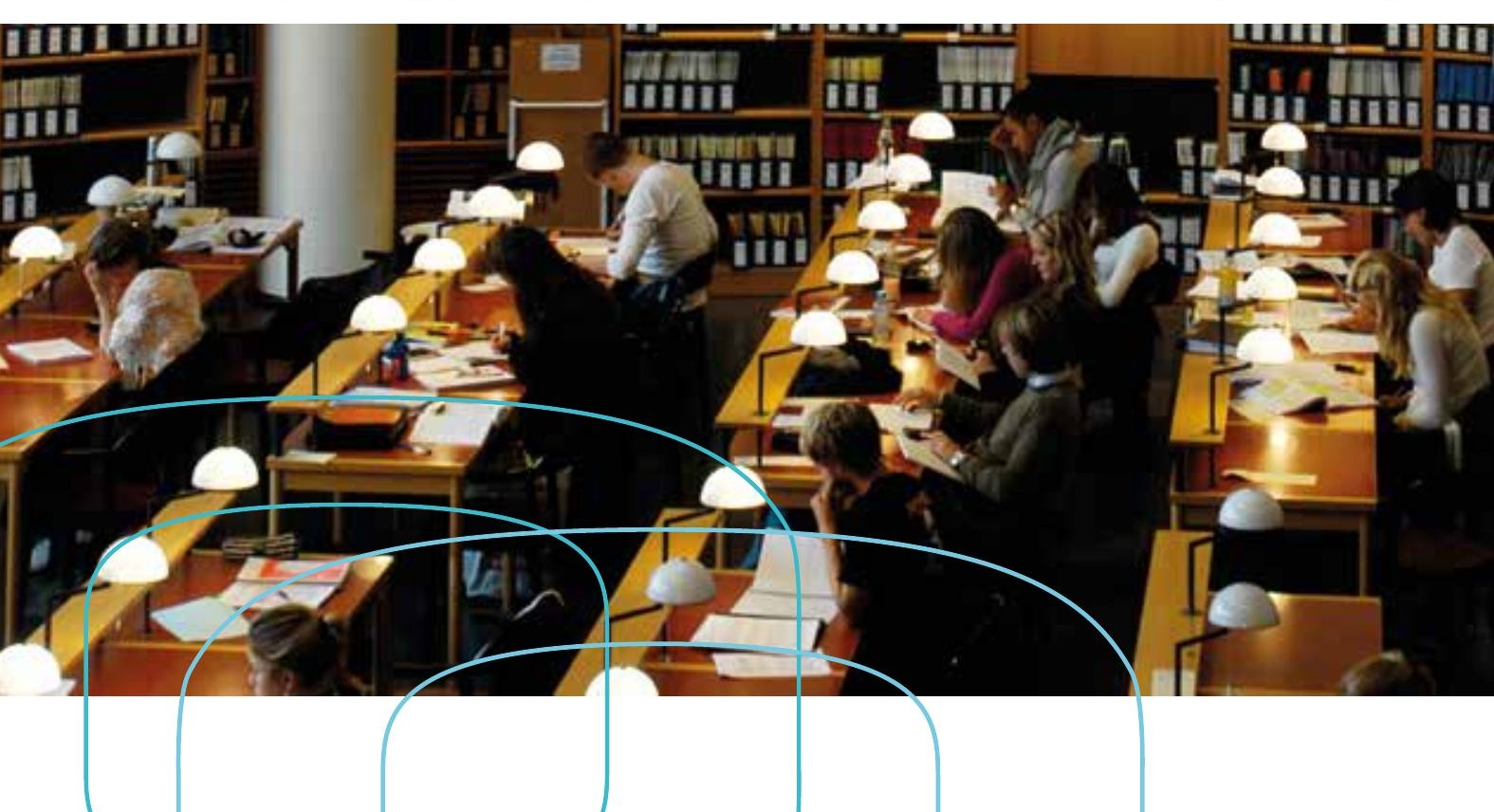


Kvalitet og relevans i uddannelser og forskning

Samarbejdsprogram for Nordisk Ministerråd for

Uddannelse og Forskning (MR-U) gældende fra 2015

ISBN 978-92-893-4202-5 (PRINT)

ISBN 978-92-893-4203-2 (PDF)

http://dx.doi.org/10.6027/ANP2015-756

ANP 2015:756

C Nordisk Ministerråd 2015

Layout: Gitte Wejnold

Omslagsfoto: Norden.org

Foto: Norden.org, Signelements.com

Tryk: Rosendahls-Schultz Grafisk

Oplag: 300

Skrift: Meta LF

Papir: Munken Polar

Printed in Denmark

www.norden.org/nordpub

\section{Nordic co-operation}

Det nordiske samarbejde er en af verdens mest omfattende regionale samarbejdsformer. Samarbejdet omfatter Danmark, Finland, Island, Norge og Sverige samt Færøerne, Grønland og Åland.

Det nordiske samarbejde er både politisk, økonomisk og kulturelt forankret, og er en vigtig medspiller i det europæiske og internationale samarbejde. Det nordiske fællesskab arbejder for et stærkt Norden i et stærkt Europa.

Det nordiske samarbejde ønsker at styrke nordiske og regionale interesser og værdier i en global omverden. Fælles værdier landene imellem er med til at styrke Nordens position som en af verdens mest innovative og konkurrencedygtige regioner.
Nordisk Ministerråd

Ved Stranden 18

DK-1061 Copenhagen K

Telefon (+45) 33960200 


\section{Kvalitet og relevans i uddannelser og forskning}

Samarbejdsprogram for Nordisk Ministerråd for Uddannelse og Forskning (MR-U) gældende fra 2015 


\section{Indledning}

De nordiske lande har en lang tradition for et tillidsbaseret samarbejde, og landene har flere fælles værdier så som demokrati, menneskerettigheder og bæredygtighed. Det formelle nordiske regeringssamarbejde i Nordisk Ministerråd har gennem årene udgjort en platform for at skabe synergier og udveksle erfaringer om løsninger på en lang række områder til gavn for borgerne i Norden. For tiden gennemgår Nordisk Ministerråd en større modernisering for at revitalisere samarbejdet og bidrage til et grænseløst, innovativt, synligt og udadvendt Norden. Det sker i en tid, hvor de nordiske velfærdssamfund samtidig udfordres af globalisering, økonomisk krise, demografiske ændringer samt klima- og energispørgsmål.

Visionen for det nordiske samarbejde om uddannelse og forskning er, at Norden også i fremtiden kan være en ledende region for kundskab og velfærd. Samarbejdet tager afsæt i ønsket om at skabe et velfungerende uddannelses- og forskningsfællesskab i Norden. De nordiske lande står hinanden nær - både geografisk, historisk og kulturelt. Uddannelsessystemerne har flere ligheder og fælles udfordringer. Landene kan opnå bedre resultater, hvis de samarbejder - til glæde og nytte for institutioner og borgerne.

Samarbejdsprogrammet for Nordisk Ministerråd for uddannelse og forskning (MR-U) sætter retningen for ministrenes samarbejde om uddannelse og forskning, sprog og it fra 2015. Programmet skal bidrage til at fokusere og målrette samarbejdet, som udspringer af de politiske dagsordener i landene og på Færøerne, Grønland og Åland. Programmet beskriver de temaer, som ministrene ønsker at give særlig opmærksomhed, og det indeholder således ikke en udtømmende oversigt over alle MR-U's prioriteringer. Samarbejdsprogrammet vil løbende blive drøftet og justeret i ministerrådet i forhold til nye politiske prioriteringer. På den måde vil det understøtte den fortsatte udvikling af MR-U's samarbejde og den måde, der samarbejdes på inden for uddannelses- og forskningsområdet. Programmet suppleres med en aktivitetsoversigt med konkrete projekter og initiativer til intern brug.

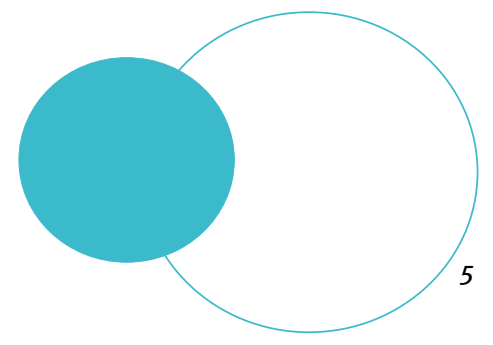




\section{Aktuelle temaer i uddannelserne}

Det nordiske uddannelsessamarbejde omfatter hele spektret fra børnehave/ førskole til grundskole, ungdomsuddannelser, voksenuddannelse og folkeoplysning samt højere uddannelse.

Det nordiske samarbejde om uddannelsesområdet 0-18 år og voksnes læring fokuserer på at styrke kvaliteten i børnehaver/førskoler, undervisning og uddannelser. Målet er at skabe uddannelser, så alle børn og unge, drenge og piger, kan blive så dygtige som de kan i et godt psykisk og fysisk læringsmiljø, at betydningen af social baggrund mindskes, og at alle får mulighed for at lære og udvikle sig gennem hele livet. Indsatsen omfatter følgende aktuelle temaer:

1. Styrke børn, unge og voksnes, drenge og pigers/kvinder og mænds, grundlæggende færdigheder og kundskaber ved at

- Fremme videns- og analysesamarbejdet om centrale udfordringer på uddannelsesområdet 0-18 år og inden for voksenuddannelserne.
- Bidrage til udvikling af de nordiske uddannelser gennem et øget fokus på styring, ledelse og implementering af reformer.

- Fremme udvikling og brug af nye undervisnings- og læringsmetoder, for eksempel gennem øget fokus på entreprenørskab, kreativitet og innovation samt digitalisering.

2. Bidrage til en god overgang mellem uddannelserne og mellem uddannelse og arbejdsliv.

\section{Styrke unge og voksnes muligheder} for at gennemføre et uddannelsesforløb, herunder at få flere unge til at gennemføre en erhvervsuddannelse.

\section{Fremme erhvervsuddannelsernes} status og bidrage til bedre rammer for læring på arbejdspladsen for unge og voksne.

Inden for højere uddannelse tager samarbejdet udgangspunkt i den øgede 
internationale konkurrence, som gør det centralt at påvise styrkeområder samt at bidrage til øget mobilitet inden for kundskabssektoren. Indsatsen omfatter følgende aktuelle temaer:

5. Stimulere til øget strukturelt samarbejde mellem nordiske højere uddannelsesinstitutioner, for eksempel inden for små akademiske områder samt videreudvikling af Nordisk Master Programmet.

6. Profilere højere uddannelse ved at fremme kvalitetssamarbejde, for eksempel ved at udveksle nationale erfaringer med at udvikle metoder til vurdering af kvalitet inden for området.

To temaer er fælles for hele uddannelsesforløbet og omfatter:

7. Styrke samarbejdet om læreruddannelsen, udøvelsen af lærerprofessionen samt efter- og videreuddannelse, så hele spektret af lærerfaget dækkes.

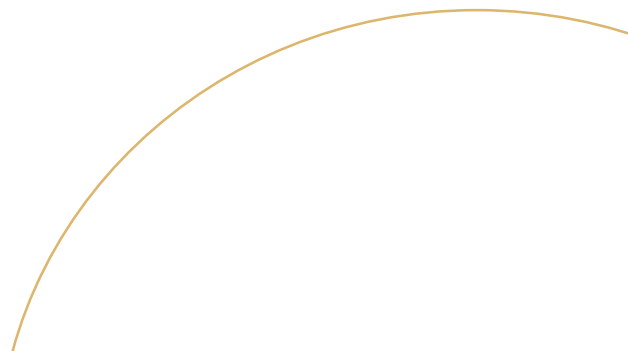

8. Styrke nordiske uddannelsesinstitutioners konkurrencekraft på det internationale marked, for eksempel ved at undersøge forudsætningerne for profilering og efterspørgslen af nordiske uddannelser internationalt.

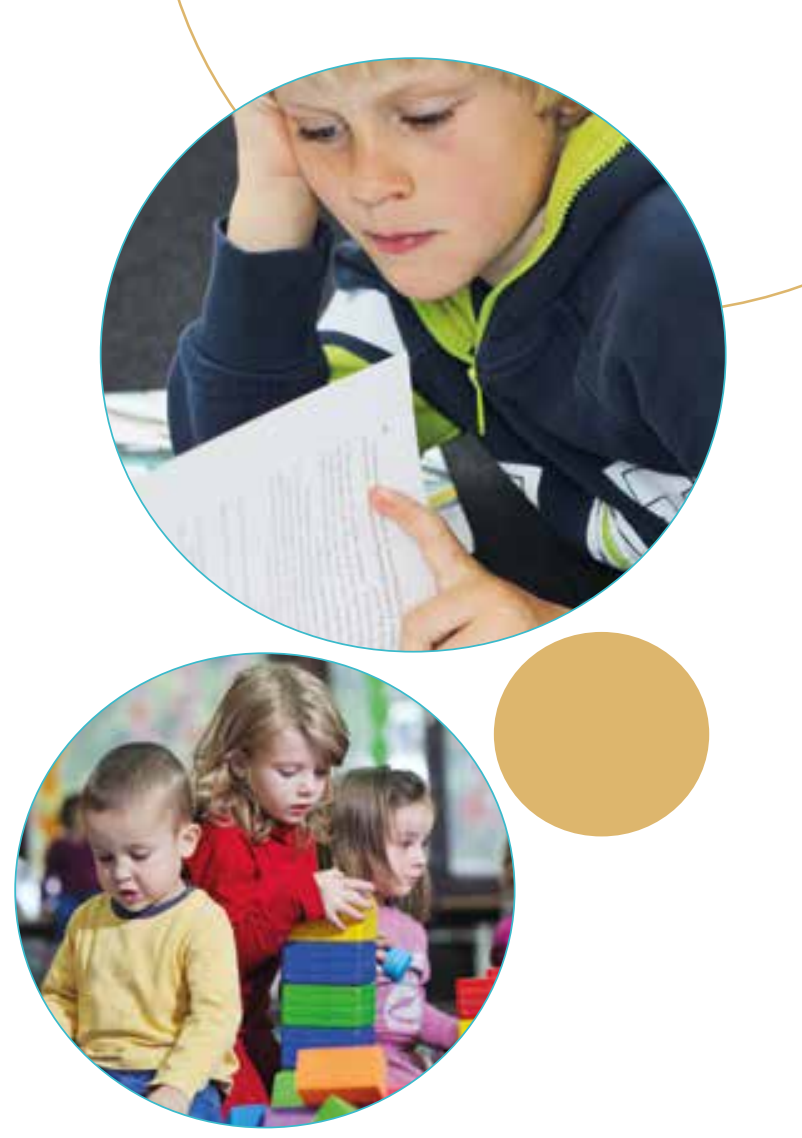




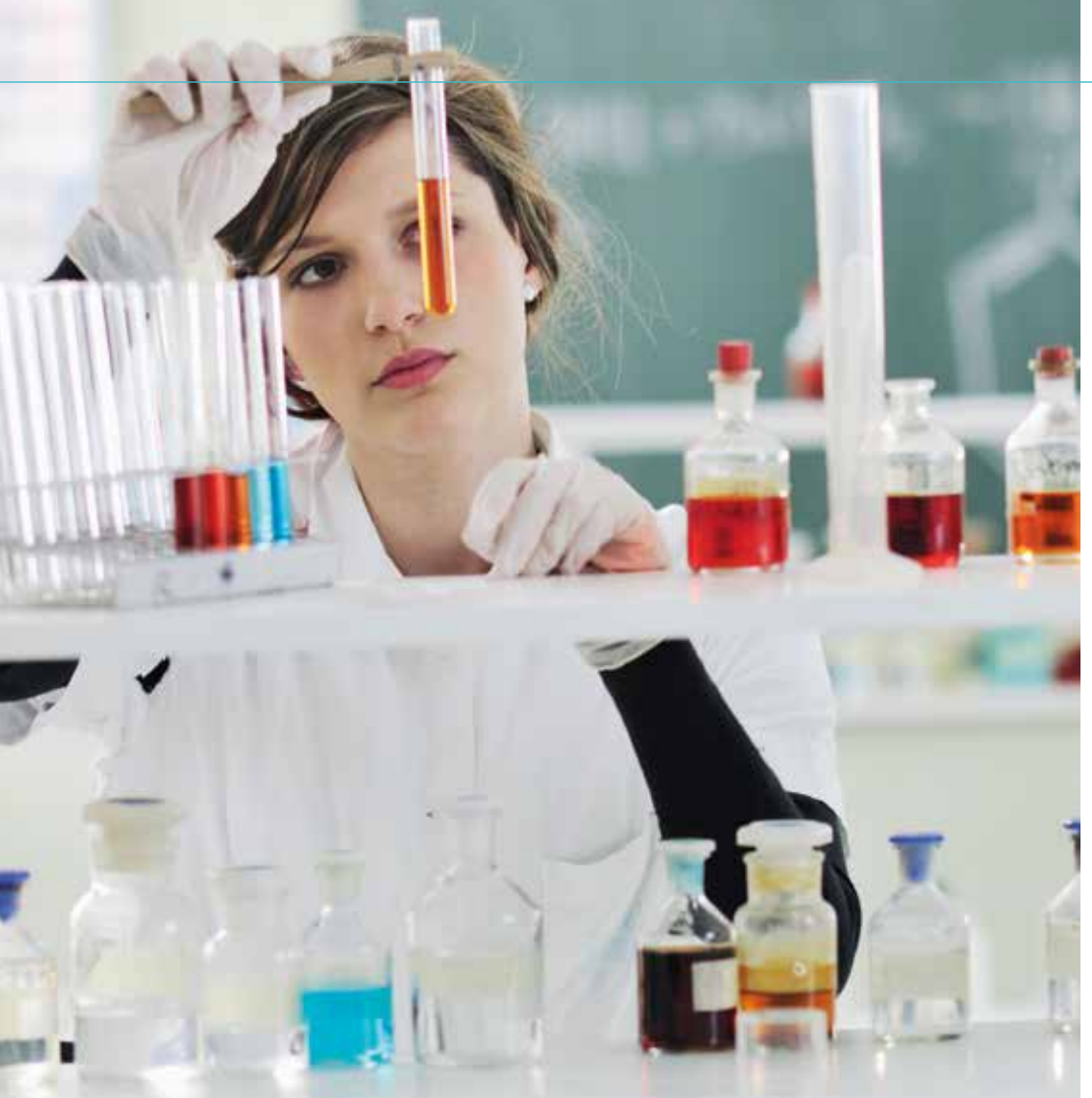




\section{Aktuelle temaer inden for forskning}

Den videnskabeligt baserede kundskab er vigtig for at skabe vækst og at håndtere forskellige samfundsmæssige udfordringer. Et udviklet nordisk forskningssamarbejde øger forskningens kvalitet og gennemslag. Samarbejdet giver desuden forskningsaktørerne og landene merværdi gennem besparelser af omkostninger og øgede muligheder for at attrahere forskningsmidler inden for EU's programmer og initiativer.

MR-U vil bidrage til, at Norden udvikler sig til en globalt ledende kundskabsregion gennem følgende aktuelle temaer:

1. Understøtte multidisciplinært og sektorovergribende forskningssamarbejde mellem nationale og nordiske forskningsfinansieringsorganer.
2. Fremme forskningssamarbejdet inden for potentielt excellente forskningsområder, inklusive strategisk betydningsfulde områder hvor en fælles nordisk satsning er nødvendig for at bygge en forskningsog uddannelseskompetence af international kvalitet og styrke.

3. Fremme samarbejde om og fælles anvendelse af forskningsinfrastruktur i Norden.

Et udviklet nordisk forskningssamarbejde kan desuden give ny kundskab inden for områder som prioriteres af MR-U, for eksempel uddannelse, nordiske sprog og sprogkommunikation. 


\section{Aktuelle temaer i sprogsamarbejdet}

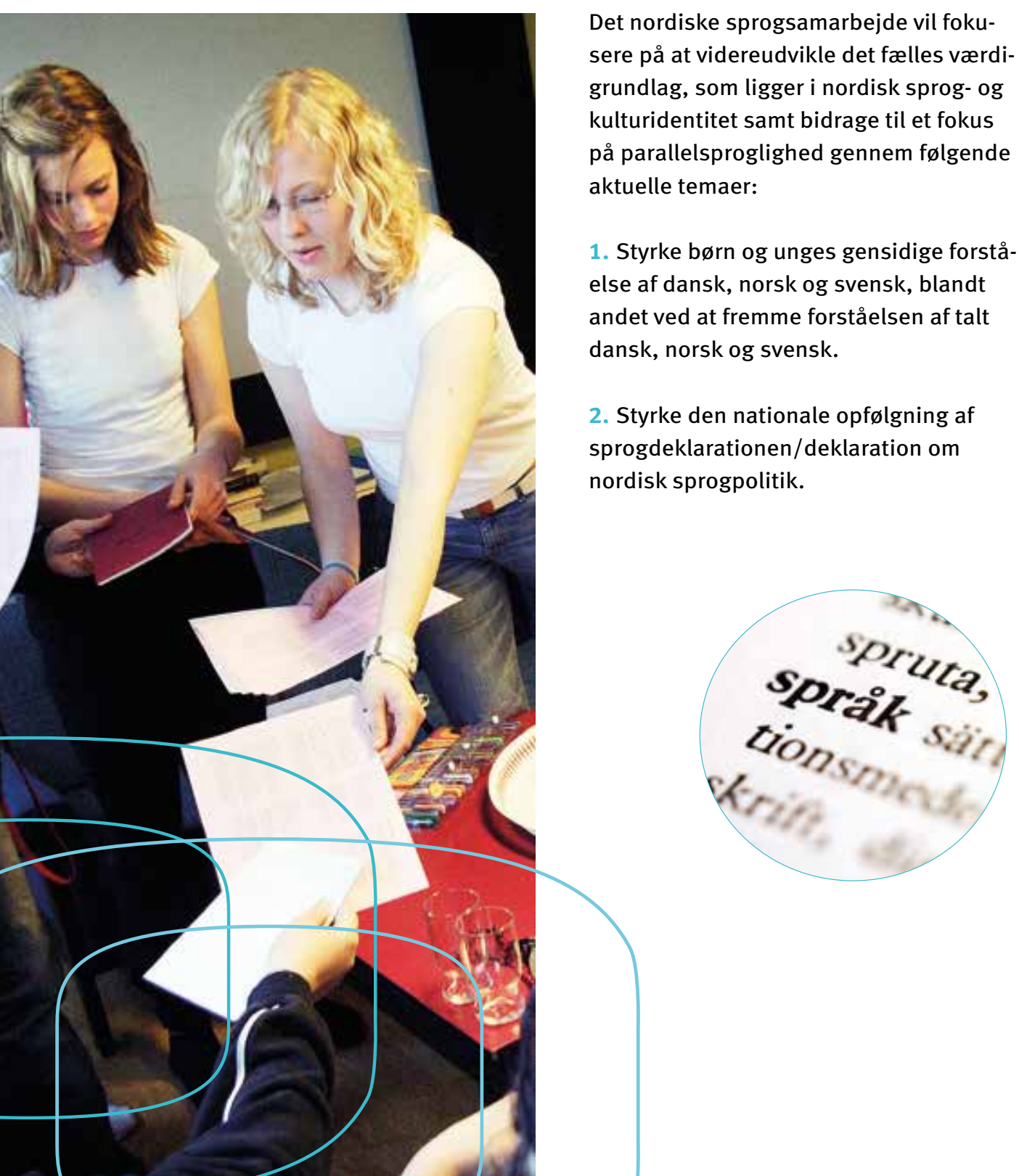




\section{Aktuelle temaer i IT-samarbejdet}

Det nordiske IT-samarbejde sigter på at gøre det lettere for borgere og virksomheder i Norden at bevæge sig på tværs af grænser og øge kvaliteten af den digitale offentlige forvaltning i Norden.

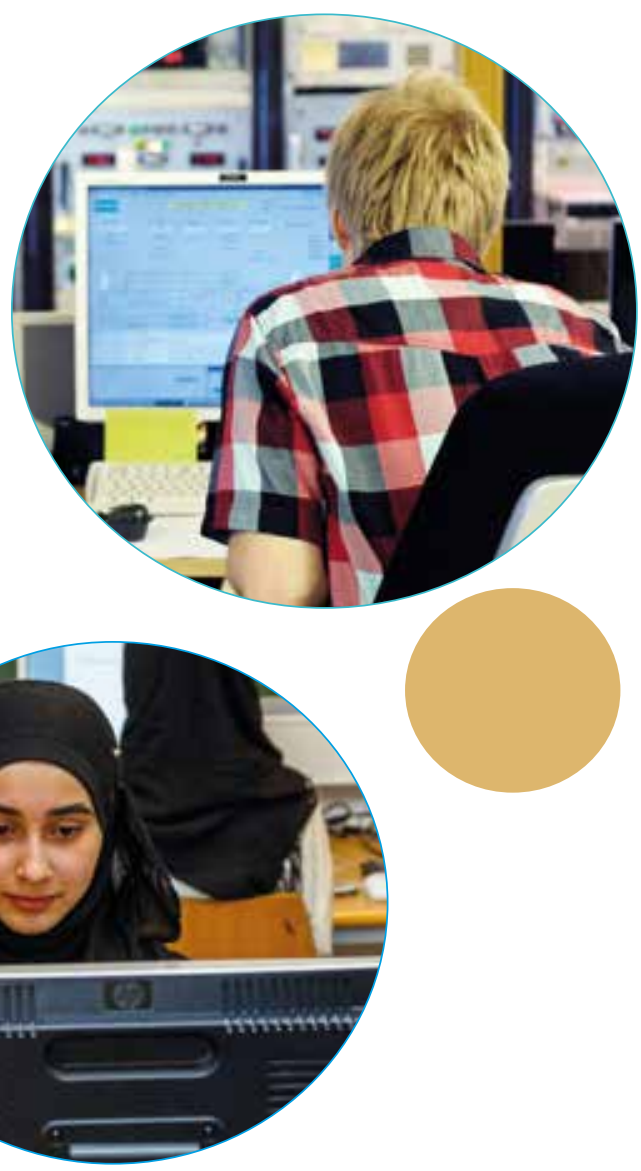




\section{Samarbejdsformer}

MR-U har en lang tradition for et intensivt og konstruktivt samarbejde om udfordringer og initiativer af fælles interesse inden for uddannelses- og forskningsområdet. MR-U vil i de kommende år varetage det langsigtede samarbejde gennem:

\section{Uddannelses-og netværksprogram-} merne:

- Nordplus

- Nordisk Master Programmet (NMP)

- Nordisk Netværk for Voksnes Læring (NVL)

- Nordisk Sprogkoordination (NOSK)

Institutionen NordForsk

De fem samarbejdsorganer:

- Nordisk Institut for Teoretisk Fysik (NORDITA)

- Nordisk Institut for Søret (NIfS)

- Nordisk Institut for Asienstudier (NIAS)

- Nordisk Vulkanologisk Institut (NORDVULK)

- Nordisk Samisk Institut (NSI)

Ad hoc arbejdsgrupper og projekter

Mødepladser for erfaringsudveksling, videndeling, læring og gensidig inspiration.
Nordiske aftaler:

- Konventionen mellan Danmark, Finland, Island, Norge och Sverige om rätten att använda nordiska språk hos myndigheterna i ett annat nordiskt land (Språkkonventionen)

- Deklaration om nordisk sprogpolitik (Sprogdeklarationen)

- Overenskomst mellem Danmark, Finland, Island, Norge og Sverige om adgang til højere uddannelse

- Nordisk deklaration om erkännande av bevis avseende högre utbildning (Reykjavik-deklarationen)

- Aftale mellem Danmark, Finland, Island, Norge og Sverige om nordisk uddannelsesfællesskab på det gymnasiale niveau

Studier, analyser, udredninger og evalueringer $m v$.

Samarbejde og dialog med nordiske sammenslutninger og organisationer inden for MR-U's portefølje.

Mange opgaver løses bedst på tværs af flere fagministerråd, og MR-U samarbejder med andre ministerråd om den konkrete udmøntning af tværgående indsatser, programmer og strategier. 
Samarbejdet sker blandt andet gennem:

- Programmet Holdbar Nordisk Velfærd (HNV)

- Programmet Uddannelse og forskning for Grøn vækst

- Samarbetsprogram för det nordiska jämställdhetssamarbetet 2015-2018

- Handlingsplan för nordiskt samarbete om funktionshinder 2015-2017

- Strategi för barn och unga i Norden

- Nordisk strategi för hållbar utveckling

- Strategi och handlingsplan för nordisk mobilitet 2014-2017 (Samarbetet om gränshinder).

MR-U samarbejder ligeledes med forskellige regionale og internationale organisationer om opgaver og muligheder af fælles interesse.

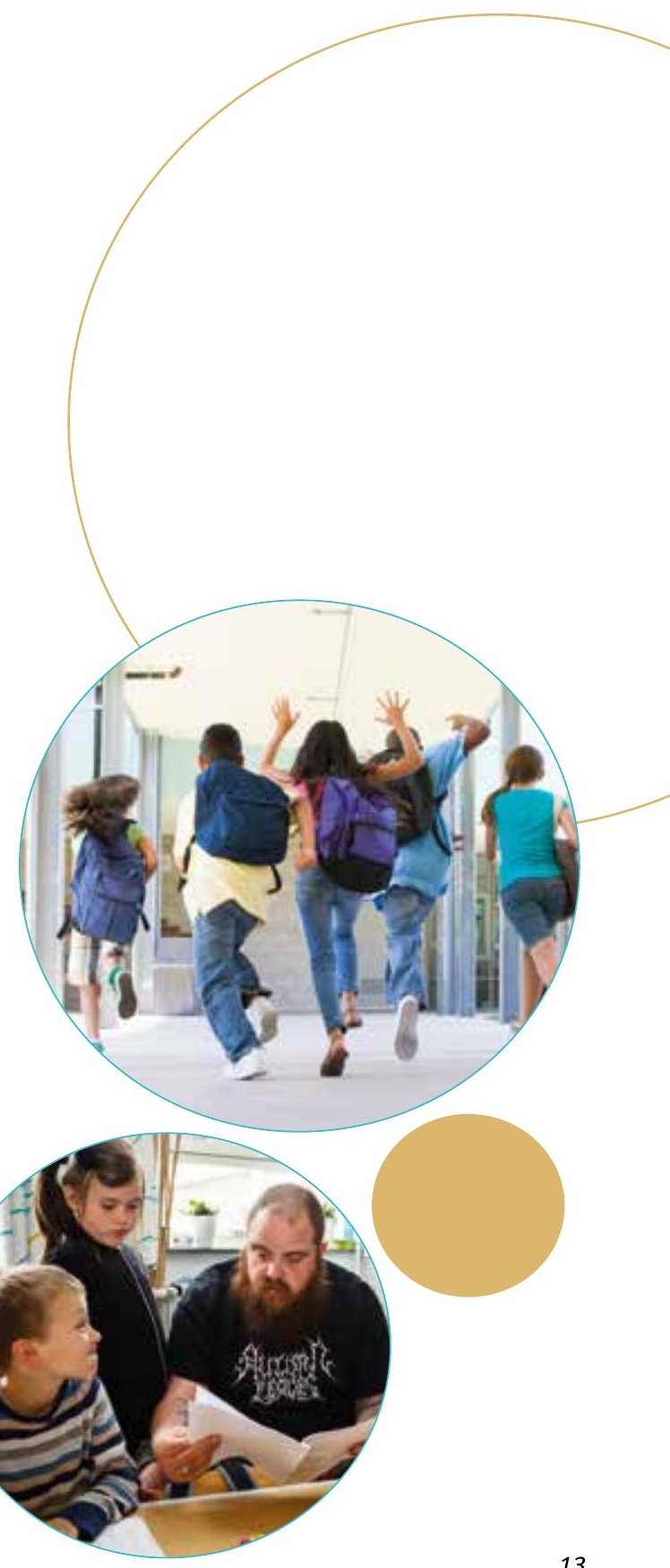



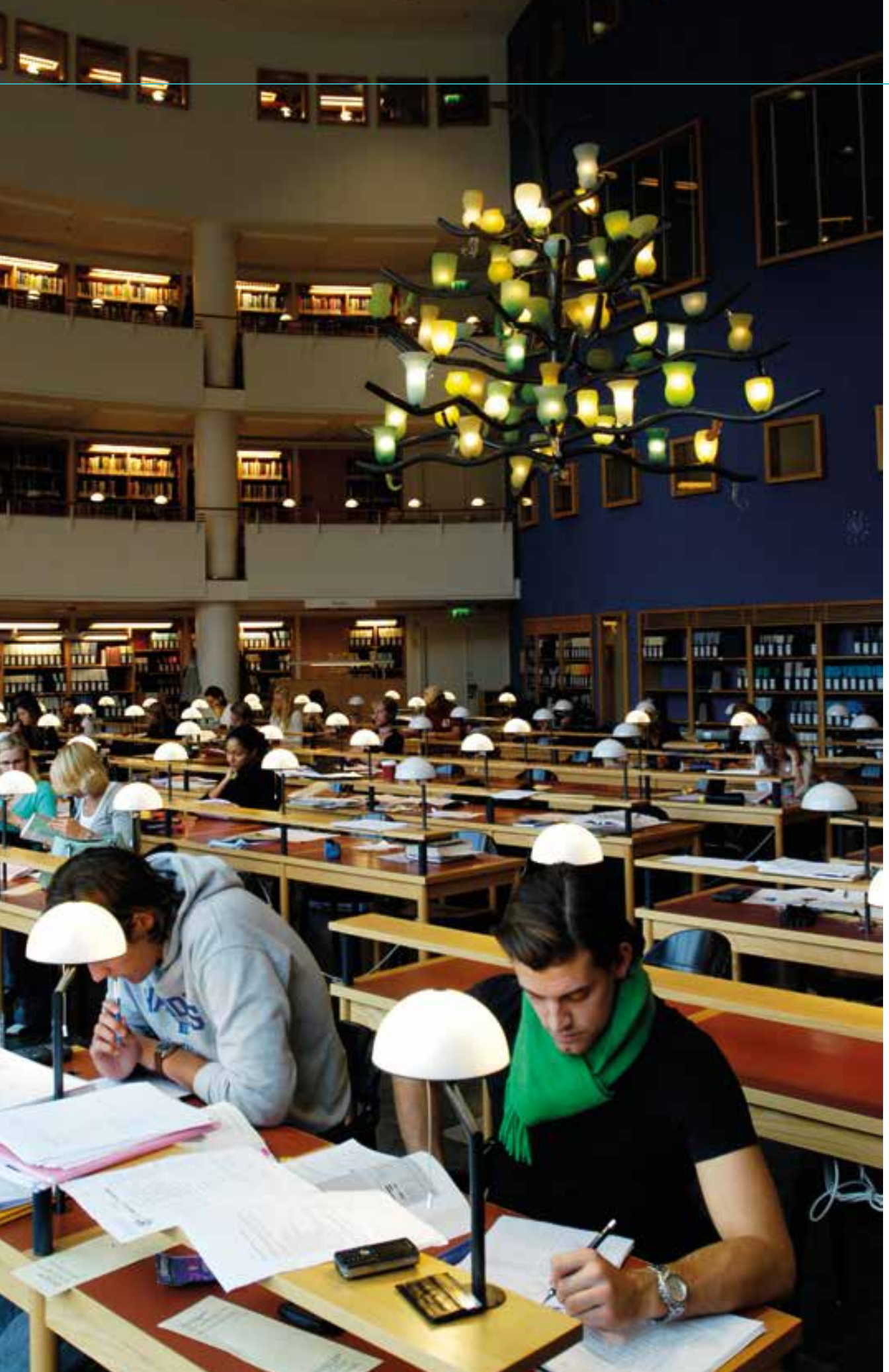


\section{Afslutning}

Målgruppen for programmet er MR-U og alle aktører under MR-U, som arbejder for at realisere målene for det nordiske samarbejde på uddannelses- og forskningsområdet.

Det er Nordisk Ministerråds ambition, at alle berørte parter vil have glæde af programmet som et pejlemærke for det fremtidige samarbejde. 


\section{norden}

Nordisk Ministerråd

Ved Stranden 18

DK-1061 København K

www.norden.org

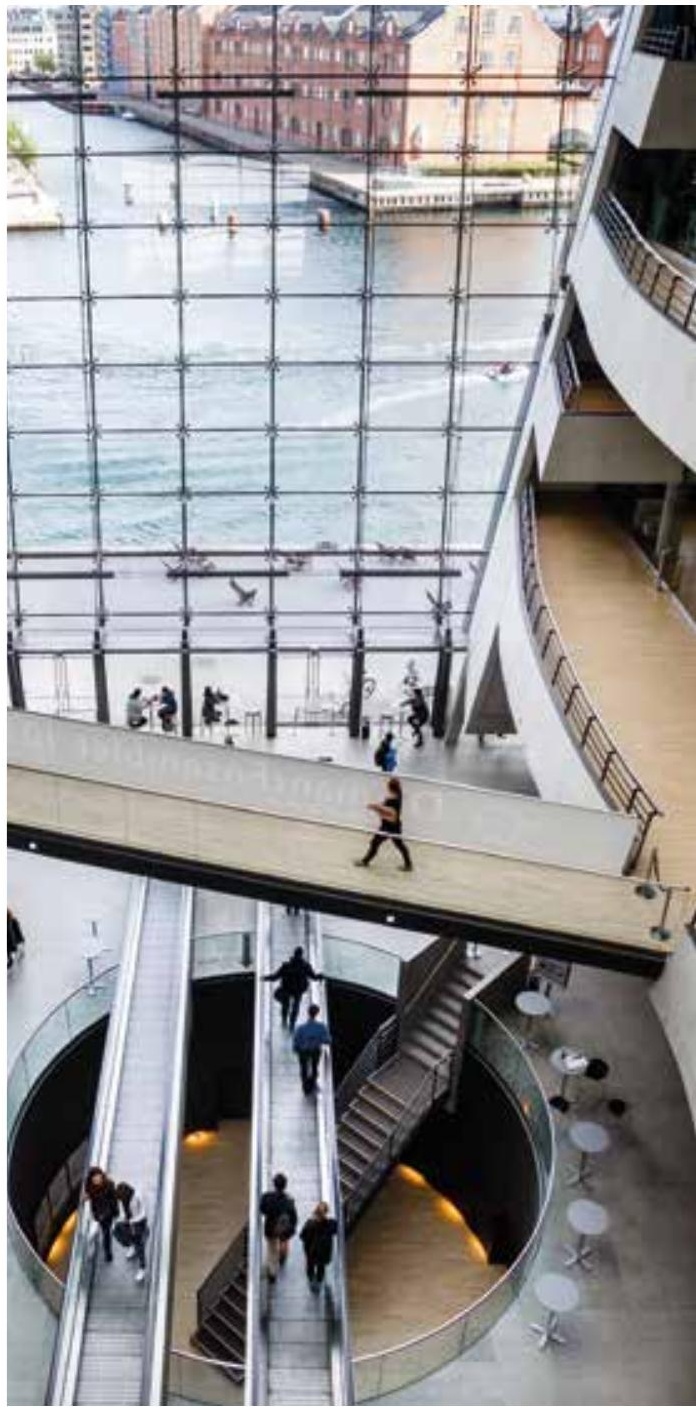

